\title{
A Survay Of The Availability And Utilization Pattern of Information And Communication Technology By French Language Teachers In Upper Basic Classes In Edo State
}

\author{
Peace Joan Alufohai \\ Department of Curriculum and Instruction, Faculty of Education \\ Ambrose Alli University, Ekpoma. Edo State -Nigeria
}

Asika J. I.

Department of Modern Languages, Faculty of Arts and Social Sciences

Ambrose Alli University, Ekpoma. Edo State -Nigeria

\begin{abstract}
The study adopted the survey design to assess teachers' use of information and communication technology in public secondary schools in Edo State. Purposive sampling technique was used to draw the sample for the study. The questionnaire titled Information and Communication Technology Availability and Utilization by French Language Teachers' Questionnaire (ICTAUFLTQ) was used to elicit information from the teachers (respondents). Data were analyzed using frequency count and simple percentage. Findings revealed that availability of computer and internet facilities, competency level of teachers on information and communication technology was very low and inadequate to cope with the recent trend. Recommendations were made and it include the fact that government needs conscious responsibility by providing adequate information and communication gadgets/facilities to the nation's upper basic classes for the effective implementation of the French language curriculum.
\end{abstract}

Keywords: Availability, Utilization, Information and communication, French language, Teachers

\section{INTRODUCTION}

The Introduction of Information and Communication Technology (ICT) has brought significant changes to the world in general and the educational sector in particular. Information and communication Technology is therefore becoming rapidly important in our day to day activities. Thus, it has become a necessity for educational institutions to use ICT to teach the skills and knowledge needed in the $21^{\text {st }}$ century. Realizing the effect of Information and Communication Technology in the world, educational institutions try to restructure their educational and classroom facilities, in order to bridge the existing technological gap in teaching and learning. This restructuring process according to Charles (2012) requires effective adoption of technology into existing environment in order to provide learners with knowledge of specific subject areas and to promote meaningful learning which will enhance professional productivity.

Information and Communication Technology is an electronic network that makes it possible to interact, access and exchange information. It is all about the technology that aid in the communication process of passing messages from the sender to the receiver. According to Unagha (2006), Information and Communication Technology encompasses computer and telecommunication. Okenwa (2008) observed that technology has advanced into the development of communication and multimedia equipment that are capable of accepting data, 
processing data into information and storing both the data information for future use and reference purpose. The scholar noted that computer based technology include: teleconferencing machine, computer electronic book (e-books), computer graphics technology, instructional satellite, video conferencing and web television.

In some advanced countries of the world like China and Japan, integration of ICT into some school subjects in the curriculum has brought changes, development and efficiency into their system (Owolabi and Owolabi, 2015). In Europe and America, a vast majority of students now study in schools and classrooms with computers and some forms of internet access (Yasamin 2007). Biggs (2008) also observed that access to computers and the internet has increased rapidly during the past decade. According to Biggs (2008), as at the year 2001, an estimated $99 \%$ of public and $87 \%$ of instructional room has internet connections. The introduction of Information and Communication Technology (ICT) as a facilitator of teaching and learning at all levels of the educational system enhance development. The government of the federal Republic of Nigeria has discovered this, hence in its National Policy on Education (2013), it was clearly stated that the government shall provide adequate infrastructure and develop capacity for effective utilization of Information Technology (IT) to enhance the delivery of Basic Education in Nigeria. It is therefore assumed that if government policy has been implemented; teachers in Nigerian school system must have acquired ICT skills which will help them for effective school system must have acquired ICT skills which will help them for effective instructional delivery as well as facilitate teaching and learning. It is on this premise that Iwiyi (2007) opined that computer acquisition and use is an important aspect of the teaching and learning process. However, studies have shown that some of these facilities are not available. According to Arize, Okonkwo and Owonor (2012), ICT availability in secondary schools in Onitsha- Nigeria is very low. Eze and Nja (2014) also concluded in their studies in Ebonyi State of Nigeria that ICT facilities were not adequate and personnel to operate them were not adequately trained.

The study of Ogundele and Etejere (2012), Akinnubi (2012), Ikumapayi (2004) reveal that the availability of computer and other facilities do not indicate effective usage. In the study carried out in south-western part of Nigeria by Tella (2011), on the level of availability, use of and perception of the impact of ICT on teacher education in Nigeria, it revealed a low level of usage of ICT gadgets; non-availability of ICT equipment and sluggish use and integration of ICT. The study of Boma and Mandah (2013) in Port-Harcourt - Nigeria also revealed that university ICT unit is grossly inadequate in terms of the gadgets and underutilization of the available gadgets.

The study of Mohammed-Jamiu (2016) concluded that ICT facilities have not been adequately provided for in secondary schools. In a study of the ICT and the problem of integration in the teaching/learning of French language carried out in Iran by Mohamad-Hossein and JeanFrancois (2012) it was discovered that the university lecturers only utilize the traditional method of teaching the language rather than utilization of ICT. According to Owolabi and Owolabi (2015), most teachers in Nigeria do not have technological training to guide themselves and their students in the use of computers to enhance their learning achievement in spite of the importance of ICT for teachers in improving knowledge. The study of Fawale (2016) also discussed the dearth of trained ICT personnel in application software and new innovation in ICT equipment in Nigerian schools. Fawale (2016) also highlighted some of the challenges facing the utilization of ICT gadgets to include poor funding shortage of power, network epileptics etc.

A critical examination of studies carried out concerning the availability and utilization of information technology revealed that there is a dearth in the area of ICT utilization in French 
language as a subject. It is against this background, this study examined the availability and utilization of ICT In the teaching of French language in Edo state upper basic classes.

\section{RESEARCH QUESTIONS}

The following research questions were raised to guide the study

1. What are the ICT facilities available for teaching French language in upper basic classes in Edo state?

2. Are ICT facilities adequate for teaching French language in upper basic classes in Edo state?

3. Are ICT Facilities utilized in teaching French language in junior secondary schools in Edo state?

4. What are the challenges faced by French language teachers who use ICT facilities in Upper basic classes in Edo State?

\section{RESEARCH METHODOLOGY}

The design adopted for this study is the descriptive survey design. The total population for the study is made up of the entire 1074 French language teaches in Edo state upper basic classes. The purposive sampling technique was used to select 100 French language teachers in five local government areas of the eighteen local government areas of Edo state.

A questionnaire titled Information and Communication Technology Availability and Utilization by French Language Teachers' Questionnaire (ICTAUFLTQ) was the instrument used for the collection of data for the study. (ICTAUFLTQ) was in two parts. The first part is part (A) and it dealt with the personal data of the respondents while the second part which is part (B) consisted of questions that elicited responses from the respondents. (ICTAUFLTQ) consisted of three sub units. Sub unit 1 consisted of eleven items that captured the availability and adequacy of ICT facilities in upper basic classes in Edo State. This sub unit 1 had (2) point scales of Yes and No to show the availability of the facilities and the percentage of the facilities. Sub unit 2 is made up of twenty items that captured French language teachers utilization of ICT in the teaching of French language and it was rated on four (4) point scales of Strongly Agree, Agree, Disagree, and Strongly Disagree. Sub unit 3 consisted of six items that examined the influence of ICT utilization by French language teachers. This sub unit was rated on four (4) scales of Strongly Agree, Agree, Disagree, and Strongly Disagree. The face content and construct validation of the instrument was carried out by experts in the Faculty of Education, AAU Ekpoma. A test-retest method was adopted in determining the reliability coefficient which was 0.70

The researcher visited the sampled secondary schools to administer the instruments. Three research assistants were trained and used for this study. The data collected was analyzed using frequency and percentage count.

\section{RESULTS}

Research Question 1: What are the ICT facilities available for teaching French language in upper basic classes in Edo state? 
Table 1: Distribution of ICT facilities used regularly by French Teachers

\begin{tabular}{|c|l|c|c|c|}
\hline S/N & ICT FACILITIES/ GADGETS & $\begin{array}{c}\text { No. of Resp. } \\
\text { per Gadget }\end{array}$ & Total resp. & Percentage (\%) \\
\hline 1 & Ipad & 0 & 100 & 0 \\
2 & Computer & 45 & 100 & 45 \\
3 & Laptop & 13 & 100 & 13 \\
4 & Multimedia projector & 9 & 100 & 9 \\
5 & Internet library & 0 & 100 & 0 \\
6 & Bill board & 25 & 100 & 25 \\
7 & Audio tape & 25 & 100 & 25 \\
8 & Interactive radio & 35 & 100 & 25 \\
9 & Television & 45 & 100 & 35 \\
10 & Projection screen & 0 & 100 & 45 \\
11 & Interactive white board & \multicolumn{2}{c}{} \\
\hline
\end{tabular}

Respondents were asked the type of ICT gadgets available/employed in their teaching. The above table revealed that 45 percent of the total respondents made use of computers and projection screen while 25 percent of the respondents indicated that they made use of bill boards and interactive radio. None indicated that they made use of ipad, internet library and interactive whiteboard. This table also shows that 25 percent of the respondents made use of radio tapes, 35 percent made use of television, 13 percent and 9 percent made use of laptop and multimedia respectively.

A cursory look at the above distribution of usage clearly indicates that majority of the schools still do not have/employ ICT facilities as instructional aid.

Research questions 2: Are ICT facilities adequate for teaching French language in upper basic classes in Edo state?

Table 2: Adequacy of ICT facilities/gadgets

\begin{tabular}{|l|c|c|c|}
\hline & \multicolumn{2}{|c|}{ Adequacy of ICT facilities } & \multirow{2}{*}{ Total } \\
\hline & YES & NO & 100 \\
\hline ICT Facilities & 14 & 86 & 100 \\
\hline
\end{tabular}

From the Table 2, majority (86\%) of the respondents who have ICT facilities/gadgets in their schools indicated that the ICT facilities are inadequate compare to students population while a few (14\%) indicated that ICT facilities in their schools are adequate.

Research Question 3: Are ICT facilities utilized in teaching French language in upper basic classes in Edo State?

Table 3: Rating of ICT Facilities Literacy Skills

\begin{tabular}{|l|c|c|}
\hline Level of ICT Facility Skill & No. of Respondents & Percentage (\%) \\
\hline Excellent & 12 & 12 \\
Very good & 4 & 4 \\
Good & 45 & 45 \\
Fair & 30 & 30 \\
No skill & 9 & 9 \\
\hline Total & 100 & 100 \\
\hline
\end{tabular}


From Table 3 above, majority of the respondents who have good ICT facility usage/skills are $45 \%$, followed by those $30 \%$ who rated their ICT facility usage/skill as fair.

Few respondents representing $12 \%$ of the total respondents rated their ICT facility usage/skill as excellent while $9 \%$ had no ICT facility usage/skill.

Research Question 4: What are the challenges faced by French teachers who use ICT facilities in upper basic classes in Edo State?

Table 4: Frequency of ICT facility usage by teachers

\begin{tabular}{|c|c|c|}
\hline Usage per week & No. of Respondents & Percentage (\%) \\
\hline 1 & 60 & 60 \\
2 & 12 & 12 \\
3 & 8 & 8 \\
4 & 10 & 10 \\
5 & 5 & 5 \\
never & 5 & 5 \\
\hline total & 100 & 100 \\
\hline
\end{tabular}

The table above indicates that majority of the teachers $(60 \%)$ use ICT facilities as teaching aids once in a week, while a total of about 35\% of the teachers made use of ICT facilities as teaching aids more than once a week. $5 \%$ of these teachers do not use it even though such facilities are present.

Table 5: Challenges faced by teachers who use ICT facility.

\begin{tabular}{|c|l|c|c|}
\hline $\mathrm{s} / \mathrm{n}$ & Challenges & No. of Respondents & Percentage (\%) \\
\hline 1 & Inadequate ICT skills & 10 & 10 \\
2 & Unstable electricity & 57 & 57 \\
3 & High rage of breakthrough & 13 & 13 \\
4 & Inadequacy & 20 & 20 \\
\hline & Total & 100 & 100 \\
\hline
\end{tabular}

Table 5 above interprets the response of French teachers regarding the challenges that they encounter when utilizing ICT gadgets/resources. From the table, it shows that $57 \%$ of the total respondents decried the high rate of unstable electricity as a major challenge, 10 (10\%) of respondents indicate that their skills are inadequate to fully harness the vast resources and possibilities of ICT and its gadgets.

Also, 20 (20\%) respondents highlighted inadequacy of ICT facilities as a challenge they constantly face while $13(13 \%)$ of the respondents highlighted high breakthrough resulting from lack of maintenance as a challenge.

\section{DISCUSSION OF RESULT}

Result on Table 1 indicates that majority of the schools still do not have ICT facilities. This is quite consistent with the findings of Arinze, Okonkwo and Owonor (2012) who found that ICT availability in secondary schools in Onitsha Nigeria is very low. This finding was also corroborated by Tella (2014) in his studies where he declared that ICT facilities were not available in the south-western part on Nigeria. The result is supported by Ogundele and Etejere (2012). Akinnubi (2012) and Ikumapayi (2004), who decried the non-availability of computers in schools, however, the report of researchers from developed world such as Europe and America indicate that ICT facilities are available in their schools (Yasamin, 2007 Biggs 2008). 
Result on Table 2 shows that ICT facilities are inadequate in the teaching of French in Edo state schools. This findings is in line with Eze and Nja (2014) who concluded in their studies carried out in Ebonyi State Nigeria that ICT facilities were not adequate. Boma and Mandah (2013) in Port-Harcourt-Nigeria also declared that ICT is grossly inadequate in terms of gadgets. This result is further supported by Mohammadu-Jamiu (2016) who concluded in his study that ICT facilities have not been adequately provided in Nigeria secondary schools.

Result on Table 3 shows that most of the French language teachers in Edo state have a very low knowledge of ICT skills. This concurs with the findings of Owolabi (2015) who declared that most Nigerian teachers do not have technological training to guide themselves and the students in the use of computers to enhance their learning achievement in spite of the importance of ICT for teachers in improving knowledge. Similarly, Eze and Nja (2014) also observed in their study that personnel to operate ICT facilities in Nigeria schools were not adequately trained. This issue of lack of knowledge of ICT skills by teachers was recently reiterated in the studies of Fawale (2016) who decried the dearth of trained personnel in application software and new innovation in the ICT equipment in Nigeria schools. These findings are however contrary to the findings of scholars in the developed countries like America and Europe (Yassamin, 2007 and Biggs, 2007).

Result on Table 4 shows that the few areas where ICT facilities are available, the teachers do not utilize them. These findings agree with that of Tella (2011) who revealed the low level of usage of ICT gadgets in the south western part of Nigeria. Similarly, Boma and Mandah (2013) in their studies decried the underutilization of the availability of ICT gadgets in schools. Mohammed-Hossein and Jean-Francois (2012) in their studies titled ICT and the problem of integration in the teaching and learning of French language in Iran declared that teaching was usually carried out using the traditional/out-dated method which is devoid of utilization of ICT facilities. However, studies in the developed world like USA and Europe indicate that ICT gadgets are $99 \%$ available and utilized in the schools (2008).

Result on Table 5 explicitly revealed the challenges faced by French teachers in the utilization of ICT facilities in schools and these challenges also hinder the proper/adequate utilization of ICT gadgets in schools. This finding is in line with the declaration of Fawale (2016) who disclosed that the problem of ICT utilization in schools is shortage of power. According to him, shortage of power is classified into two aspects which are power failure and power fluctuation. ICT gadgets rely on power to function. Funding was discovered in the study to be another challenge hindering the effective utilization of ICT facilities. Most of the facilities when broken down are not repaired. This finding again is in line with Fawale (2016) who decried inadequate funding in schools.

\section{CONCLUSION}

This study investigated the availability and utilization pattern of Information and Communication Technology by French language teachers in upper basic classes in Edo State. Data collected and analyzed revealed that ICT facilities are not available in most schools and where they are available, they are not adequate. It was also revealed in the study that most of the facilities are not adequately utilized due to one challenge or the other. The findings of this study completely agreed with the studies of most Nigerian researchers cited in this work. From the foregoing therefore, it is clear that the availability and utilization pattern of ICT facilities/gadgets in the teaching of French language in Edo state is still at its lowest ebb. 


\section{RECOMMENDATIONS}

Arising from the study are the following recommendations:

1. The government should provide ICT facilities in schools for the effective implementation of the French language curriculum.

2. French language teachers should be sent for in-service training in the utilization of ICT gadgets.

3. French language teachers on their own should strive to enhance their skills in the utilization of ICT gadgets

4. Nigeria as a nation needs to wake up in the area of power. The government should provide power because ICT cannot function without power.

5. Special fund should be provided in Nigeria secondary schools for the repair of broken down ICT facilities.

\section{References}

Akinnubi, O.P. (2012). Integrating information and communication technology into tertiary institution programme. First Africa Teachers Regulatory Council Conference Proceedings of paper presented at Republic of Benin Held on $15^{\text {th }}-20^{\text {th }}$ May, 2012.

Biggs, J.C. (2008). New technologies, the new identities (2nd ed), New York: Macmillan Publishers Ltd.

Fawale, A.A. (2016). The inclusion of ICT in the Curriculum of Business Education at the University level; Problems and Prospects. Al-Hikmah Journal of Education, 3 (1) 58-68.

Ikumapayi, J.A. (2014). Networking System in Nigeria. challenges and solutions. In Oladejo, J.O. \& Opadokun, N.A. (eds). New Dimension of Education. Asaba: Joyce Press.

Mohamad-Hossein, O. and Jean-Francois, B. (2004). ICT and the problem of integration in the teaching/learning of

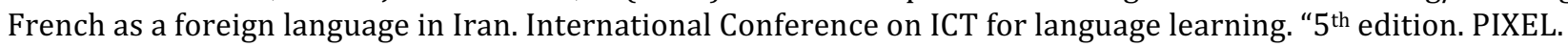
Retrieved from conference. Pixel-online.net on the $26^{\text {th }}$ Aug, 2016.

Mahammed-Jamiu, I. (2016). Wireless Mobile Communication Technology Devices in Nigeria University: Roles and Barriers. Al-Hikman Journal of Education 3(1) 1-10.

Ogundile, M.O. \& Etejere, P.A.O. (2012). Computer literacy and administration effectiveness of secondary schools in Kwara State, Nigeria. African Journal of Teachers' Education 3(1) 25-33.

Okenwa, G.N. (2008). Meeting the challenges of information technology: Case for reform in distance education programmes. Proceedings of First International Conference of Faculty of Education, University of Nigeria, Nsukka. 197-201.

Owolabi, B.O. \& Owolabi, B.G. (2015). Information communication technology (ICT). utilization for instructional delivery in teaching/learning process in Nigeria educational system. International Journal of Scientific \& Engineering Research 6 (11), 28-34.

Unuage, (2006). The usage of ICT for secondary education in Mongola. International Journal of Education \& Development in Information and Communication Technology. (IJEDICT) 1(4), 101-118.

Yasamin, C. (2007). A legacy of lifelong learning (4th ed). New York: Trenchent books. 